\title{
Association between dietary sodium, calcium, saturated fat and blood pressure in obese Egyptian adolescents
}

\author{
Nayera E. Hassana', Salwa M. El Shebinib², Sahar A. El-Masrya ${ }^{*}$, Nihad H. Ahmedb², Manal M. Alia', \\ Gamila S. M. El-Saeedc ${ }^{3}$ and Dalia El-Lebedyd ${ }^{4}$
}

\begin{abstract}
Background: Overweight/obesity, high dietary fat, sodium and low calcium intake are recognized as risk factors for primary hypertension in obese adults, children and adolescents.

Aim: The aim of this work was to assess the association between some dietary factors (fat, sodium, calcium) and blood pressure (BP) among obese Egyptian adolescents.

Subjects and methods: Seventy-seven adolescents shared in this study. Their height and weight were reported. Body mass index (BMI) was calculated. Blood pressure was measured; the mean values were corrected for age and sex in the form of centile. Dietary interview consisting of $24 \mathrm{~h}$ recall was performed. Fasting blood glucose and serum lipid profile were determined.
\end{abstract}

Results: Data revealed that, the percent of the prehypertensive was $42.86 \%$ and $38.80 \%$, for boys and girls, no hypertensive cases were recorded. The mean values of their weight, DBP, and the serum lipid parameters were high compared to their controls; significant differences were found between the daily intake of calories, protein, carbohydrate, dietary fiber and cholesterol at $p \leq 0.05$. The mean values of the daily intake of the vitamins and minerals were low in all groups compared to the RDAs, except sodium intake which was high in the prehypertensive boys and normal and prehypertensive girls.

Conclusion: This study showed a high incidence of pre-hypertension among obese Egyptian adolescents, which is associated with high intake of sodium, saturated fat and cholesterol, along with low intake of calcium.

Keywords: Dietary sodium, Calcium, Saturated fat, Blood pressure, Obesity, Adolescents, Egypt

\section{Introduction}

The prevalence of hypertension is high and increasing worldwide [1]. In several recent studies in Western countries the prevalence of high blood pressure among children was found to range from 7 to $19 \%$ [2-4]. Similar studies in developing countries were rare. The prevalence of hypertension among primary Kuwait students was 5.1\% [5], 3.6\% among school children in Jordan [6], and 4.30\% among preparatory school children in Alexandria [7]. Lifestyle factors, obesity and positive family history of hypertension are the main causes of primary hypertension [8].

\footnotetext{
* Correspondence: sa.el-raufe@nrc.sci.eg

${ }^{1}$ Biological Anthropology Department, Medical Research Division, National

Research Centre, 33 El-Bohooth St., Dokki, Giza 12622, Egypt

Full list of author information is available at the end of the article
}

Hypertension in young not only leads to hypertension in adulthood [9], it additionally builds their risk for the early development of cardiovascular disease and death $[10,11]$.

Overweight/obesity and high sodium consumption are perceived as risk variables for hypertension in adults and also in children. Sugiyama et al. [12], He and MacGregor [13], reported that of 20 observational investigations on sodium consumption and blood pressure in the young, most have demonstrated a positive correlation. Consequences of a meta-investigation from 10 randomized controlled trials demonstrated that modest decrease in young' sodium consumption was associated with a small but significant reduction in BP [14]. In spite of the fact that several trials among grown-ups and adolescents have stated that decreasing sodium intake might result 
in reducing $\mathrm{BP}$, however this relationship may be affected by weight status or presence of metabolic disorder [15], in addition analysis the relationship between sodium consumption and BP by weight status or both on the risk for developing hypertension among children and adolescents is constrained.

Kajale et al. [16], stated that low dietary calcium consumption and high adiposity may raise the risk for the development of hypertension. In this context, Mushengezi and Chillo [17] announced higher BMI and WC as indicator for the mean blood pressure. In addition, Skinner et al. [18] reported the association between higher dietary calciumconsumption and lower body and trunk fat in young adult subsequent to adjusting for physical activity. Morikawa et al. [19], reported healthy effect of increased calcium consumption/supplementation with calcium on BP. In this setting, it has been accounted that utilization of low fat and high fat dairy, milk, yogurt and cheese secures against metabolic disorder including hypertension [20].

Multifactorial dyslipideamia, described by raised total cholesterol (TC) or low-density-lipoprotein cholesterol (LDL-C), is linked with atherosclerosis in young adulthood. Screening for dyslipideamia in adolescence could postpone or decrease cardiovascular disease in adulthood [21].

The aim o the work was to assess the association between some dietary factors (sodium, calcium, fat) and cardiovascular risk factors, blood pressure among obese Egyptian children and adolescents.

\section{Subjects and methods}

Eighty-three families, shared as volunteers in this cohort prospective study. These families comprised of 83 mothers and 159 offspring, (82 children and 77 adolescents). They were enrolled in a program for nutritional education through a project funded by National Research Centre (NRC) Egypt, 2013-2016: titled "Familiar Overweight and Obesity in Children and Adolescents: Diagnostic Clinical, Behavioral, Genetic and Biochemical Markers and Intervention", after taking approval from Ethical Committee of NRC (Registration Number is 13/168) and written informed consent from each of them.

All studied adolescents (77); of both sex (35 males and 42 females) aged 12 up to 18 years; shared in this study were subjected to full history taking and physical examination including anthropometric assessment, dietary recalls, measurement of blood pressure, and laboratory investigation.

\section{Anthropometric parameters}

Relevant anthropometric measurements were reported including height and weight using standardized method [22]. Body weight was measured using a Seca scale (Seca Balance Beam Scale Model 700, Seca deutschland Medical
Scales and Measuring Systems seca gmbh \& co. kg. Hamburg, Germany) approximated to the nearest $0.01 \mathrm{~kg}$, and with minimal clothes on, for which no correction was made, and body height without shoes using a Holtain stadiometer (The Harpenden Portable Stadiometer, Wales, UK) approximated to the nearest $0.1 \mathrm{~cm}$. Body mass index (BMI) was calculated as weight in $\mathrm{kg} /$ height in meter [2].

\section{Dietary recalls}

Information from each adolescent about his usual pattern of food intake was obtained. Data was collected by means of dietary interview consisting of $24 \mathrm{~h}$ recall that repeated for 3 days, and a food frequency questionnaire.

Analysis of food items was done using World Food Dietary Assessment System, (WFDAS), 1995, USA, University of California [23].

\section{Blood pressure measurement}

Blood pressure was measured using the standardized mercury sphygmomanometer with cuff of suitable size. It was measured on the right arm after the participant was sitting quietly for $5 \mathrm{~min}$. Two readings were obtained, and the average was recorded. Systolic blood pressure (SBP) was determined by the onset of the "tapping" korotkoff sounds (K1), while the fifth korotkoff sound (K5), or the disappearance of korotkoff sounds, as the definition of diastolic blood pressure (DBP). The mean values of blood pressure were measured and corrected for age and sex in the form of centile and compared with US National Childhood Blood Pressure standards [24]. The blood pressure percentiles were determined accordingly.

\section{Blood sampling and biochemical analysis}

Venous blood samples were obtained in the morning by venipuncture after 12-h overnight fasting to measure serum lipid profile [triglycerides (TG), total cholesterol (TC) and high density lipoprotein (HDL) by ELIZA technique. The blood samples were left to clot; sera were separated by centrifugation for $10 \mathrm{~min}$ at $5000 \mathrm{rpm}$ then stored at $-80{ }^{\circ} \mathrm{C}$ until assays. Plasma concentrations of total cholesterol [25], triglycerides [26], and high-density lipoprotein-cholesterol (HDL-C) [27], were measured using commercially available kits provided by STANBIO Laboratory Inc. (1261 North Main Street Boerne Texas 78006 USA). LDL-C was calculated according to an equation developed by Friedewald et al. [28] as follows:

$$
\begin{aligned}
\mathrm{LDL}-\mathrm{C}= & \text { Total cholesterol }- \text { Triglycerides } / 5 \\
& + \text { HDL }-\mathrm{C}
\end{aligned}
$$

Fasting Plasma Glucose (FPG) on a venous clotted sample type centrifuged and the serum was isolated by the 
Table 1 Mean \pm SD of Age, Weight, Height and BMI, of obese adolescent under the study

\begin{tabular}{llll}
\hline Sig. & Female $(\mathrm{N}=42)$ & Male $(\mathrm{N}=35)$ & Groups \\
\hline 0.24 & $15.62 \pm 2.42$ & $15.84 \pm 2.31$ & Age $(\mathrm{yrs})$ \\
$0.03^{*}$ & $86.46 \pm 4.56$ & $84.59 \pm 5.91$ & Weight $(\mathrm{kg})$ \\
$0.01^{* *}$ & $158.02 \pm 10.32$ & $161.42 \pm 11.38$ & Height $(\mathrm{cm})$ \\
0.15 & $34.63 \pm 5.06$ & $32.47 \pm 4.69$ & BMl $\left(\mathrm{kg} / \mathrm{m}^{2}\right)$ \\
0.13 & $122.40 \pm 3.67$ & $123.21 \pm 3.01$ & S B P $(\mathrm{mmHg})$ \\
$0.02^{*}$ & $83.05 \pm 3.09$ & $85.13 \pm 2.04$ & D B P $(\mathrm{mmHg})$ \\
\hline
\end{tabular}

SBP: Systolic blood pressure DBP: Diastolic blood pressure

*Significant at $p \leq 0.05$

**Significant at $p \leq 0.01$

device (Beckman, Synchron chemical system CK5). Fasting was defined as no caloric intake for at least $8 \mathrm{~h}$ [29].

\section{Statistical analysis}

All values were expressed as mean value \pm SD. Two tailed student $t$-test was used to compare between the groups. Correlation between the different parameters was tested by Pearson test. P values $<0.05$ were considered statistically significant. SPSS window software version 17.0 (SPSS Inc. Chicago, IL, USA, 2008) was used.

\section{Results}

Table 1 showed the mean \pm SD of age, weight, height, BMI and blood pressure, of obese adolescents' males and females under the study. The mean age of the participated in the study was 15.84 and 15.62 year for males and females respectively, with insignificant differences. Significant differences were found between both sexes in the mean values of the body weight, height and diastolic blood pressure (DBP), where males were taller and had higher DBP, and females had heavier weight.

Table 2 showed the number and percent distribution of the studied sample according to their blood pressure. The percent of the prehypertensive boys was $42.86 \%$, while it was $38.80 \%$ for girls. No hypertensive cases were recorded among our sample.

Table 3 showed the mean age, anthropometric and biochemical parameters of the males and females of the studied sample. The mean values of the weight, DBP, (TC), LDC-C and TG of the prehypertensive boys and girls were significantly higher, while HDL-C concentration was lower compared to their controls.

Table 4 showed the mean \pm SD of the daily nutrients intake of the studied sample and its percent compared to the Recommended Daily Allowance (RDAs) and Recommended Daily Intakes (RDIs). Data shows that the prehypertensive males and females consumed higher amount of calories, protein, carbohydrate, total fat, saturated fat, polysaturated fat and cholesterol compared to control, significant differences were found between caloric, protein, carbohydrate, dietary fiber and cholesterol at $\mathrm{p} \leq 0.05$. The mean values of the daily intake of the vitamins and minerals was low in all groups compared to the RDAs, except that of the daily sodium intake which was higher than the RDAs in the prehypertensive boys and both normal and prehypertensive girls.

Table 5 showed the correlation coefficient of SBP\& DBP and the calcium, sodium, saturated fatty acids and cholesterol. Negative association was found between daily calcium intake and both systolic and diastolic BP. Positive association was reported between daily sodium, saturated fatty acids, cholesterol intake and SBP and DBP, the association did not reach the level of significant.

\section{Discussion}

Distinguishing dietary variables related with (BP) in children and adolescents would help direct suggestions for avoidance of increased BP, which is a noteworthy general medical issue. Hypertension among adolescence is associated with hypertension in adulthood [9], and additionally lead to development of atherosclerosis [30]. Moreover, dyslipideamia among adolescence is related with dyslipideamia in adulthood and an increased danger of cardiovascular disease (CVD) [31, 32].

Raj et al. [33] revealed that in Indian children the commonness of hypertension (BP >95th centile) was $(7 \%)$ in young males and $(5 \%)$ in young females. Children with pre-hypertension (BP from 85th to 95th centile) and those with hypertension had altogether higher weight and BMI, Z scores, waist circumference (WC), fat\% and

Table 2 Distribution of the obese adolescents under study according to Blood pressure levels

\begin{tabular}{|c|c|c|c|c|c|c|}
\hline \multirow[t]{2}{*}{ Parameters } & \multirow{2}{*}{$\begin{array}{l}\text { S B P }(\mathrm{mmHg}) \text { All adolescents } \\
\text { Mean } \pm \text { SD }\end{array}$} & \multirow{2}{*}{$\begin{array}{l}\text { D B P }(\mathrm{mmHg}) \text { All adolescents } \\
\text { Mean } \pm \text { SD }\end{array}$} & \multicolumn{2}{|c|}{ Male $(\mathrm{N}=35)$} & \multicolumn{2}{|c|}{ Female $(\mathrm{N}=42)$} \\
\hline & & & NO & $\%$ & $\mathrm{NO}$ & $\%$ \\
\hline Normal & $117.16 \pm 2.63$ & $74.24 \pm 2.31$ & 20 & 57.14 & 26 & 61.20 \\
\hline Pre hypertension & $122.31 \pm 2.74$ & $83.02 \pm 2.54$ & 15 & 42.86 & 16 & 38.80 \\
\hline Hypertension & 0.0 & 0.0 & 0.0 & 0.0 & 0.0 & 0.0 \\
\hline All & $122.24 \pm 2.50$ & $83.79 \pm 2.81$ & 35 & 100 & 42 & 100 \\
\hline
\end{tabular}

Normal blood pressure: SBP and DBP <90th percentile

Pre hypertension: SBP or DBP 90th percentile to $<95$ th

Hypertension: SBP and/or DBP $\geq 95$ th 
Table 3 Mean \pm SD of Age, Weight, Height, BMI and some Biochemical parameters, of males \& females obese adolescents

\begin{tabular}{|c|c|c|c|c|c|c|}
\hline \multirow[t]{2}{*}{ Parameter } & \multicolumn{3}{|l|}{ Males } & \multicolumn{3}{|l|}{ Females } \\
\hline & Normal & Pre hypertension & $P$ & Normal & Pre hypertension & $P$ \\
\hline Age (yrs) & $15.64 \pm 0.34$ & $15.57 \pm 0.64$ & 0.20 & $15.55 \pm 0.27$ & $15.49 \pm 0.33$ & 0.22 \\
\hline Weight (kg) & $82.69 \pm 8.21$ & $84.71 \pm 9.34$ & $0.04^{*}$ & $83.77 \pm 6.20$ & $86.54 \pm 6.32$ & $0.03^{*}$ \\
\hline Height (cm) & $161.53 \pm 10.43$ & $160.67 \pm 11.29$ & $0.03^{*}$ & $158.37 \pm 10.74$ & $157.54 \pm 12.47$ & $0.02^{*}$ \\
\hline BMI $\left(\mathrm{kg} / \mathrm{m}^{2}\right)$ & $33.23 \pm 3.09$ & $34.70 \pm 4.39$ & 0.31 & $33.40 \pm 3.43$ & $34.90 \pm 5.17$ & 0.32 \\
\hline S B P (mmHg) & $121.24 \pm 2.08$ & $123.57 \pm 3.05$ & $0.05^{*}$ & $122.04 \pm 2.11$ & $123.74 \pm 3.20$ & 0.23 \\
\hline D B P (mmHg) & $79.41 \pm 3.13$ & $85.27 \pm 4.50$ & $0.03^{*}$ & $77.16 \pm 1.03$ & $83.87 \pm 2.42$ & $0.04^{*}$ \\
\hline FBS (mg/dl) & $95.21 \pm 14.10$ & $96.01 \pm 11.25$ & 0.26 & $95.32 \pm 10.45$ & $94.72 \pm 11.31$ & 0.35 \\
\hline TC (mg/dl) & $191 \pm 11.03$ & $219 \pm 8.66$ & $0.02^{*}$ & $189 \pm 7.14$ & $208 \pm 10.02$ & $0.03^{*}$ \\
\hline TG (mg/dl) & $93.27 \pm 20.13$ & $112.34 \pm 15.47$ & $0.04^{*}$ & $91.64 \pm 12.61$ & $110.18 \pm 13.24$ & $0.02^{*}$ \\
\hline HDL-C (mg/dl) & $67.17 \pm 4.53$ & $86.20 \pm 6.20$ & $0.01^{*}$ & $66.10 \pm 4.05$ & $89.41 \pm 4.57$ & $0.02^{*}$ \\
\hline LDL-C (mg/dl) & $90.24 \pm 4.68$ & $176.86 \pm 7.56$ & $0.03^{*}$ & $89.57 \pm 6.23$ & $171.98 \pm 8.77$ & $0.04^{*}$ \\
\hline
\end{tabular}

*Significant at $p \leq 0.05$

Table 4 Mean \pm SD \&\% of RDAs \& DRls of the nutrients intake among obese adolescent under study

\begin{tabular}{|c|c|c|c|c|c|c|}
\hline \multirow[t]{2}{*}{ Nutrient intake } & \multicolumn{3}{|l|}{ Male } & \multicolumn{3}{|l|}{ Female } \\
\hline & Normal & Pre hypertension & Sg. & Normal & Pre hypertension & Sg. \\
\hline Energy (Cal) & $\begin{array}{l}2223.01 \pm 68.04 \\
74.100 \%\end{array}$ & $\begin{array}{l}2338.13 \pm 88.35 \\
77.93 \%\end{array}$ & $0.032^{*}$ & $\begin{array}{l}2350.32 \pm 55.09 \\
102.18 \%\end{array}$ & $\begin{array}{l}2536.30 \pm 121.27 \\
110.27 \%\end{array}$ & $0.041^{*}$ \\
\hline Protein (g) & $\begin{array}{l}66.60 \pm 3.40 \\
112.88 \%\end{array}$ & $\begin{array}{l}68.94 \pm 16.25 \\
116.84 \%\end{array}$ & 0.22 & $\begin{array}{l}65.79 \pm 12.55 \\
149.52 \%\end{array}$ & $\begin{array}{l}70.75 \pm 10.24 \\
160.79 \%\end{array}$ & $0.019^{*}$ \\
\hline Fat (g) & $123.50 \pm 1.20$ & $129.98 \pm 21.57$ & $0.021^{*}$ & $133.91 \pm 32.52$ & $134.29 \pm 30.06$ & 0.156 \\
\hline Carbohydrate(g) & $\begin{array}{l}211.28 \pm 38.20 \\
162.52 \%\end{array}$ & $\begin{array}{l}223.14 \pm 42.13 \\
171.64 \%\end{array}$ & $0.024^{*}$ & $\begin{array}{l}220.51 \pm 48.12 \\
169.62 \%\end{array}$ & $\begin{array}{l}261.17 \pm 37.21 \\
200.90 \%\end{array}$ & $0.019^{*}$ \\
\hline Dietary fiber (g) & $\begin{array}{l}15.52 \pm 5.28 \\
39.47 \%\end{array}$ & $\begin{array}{l}14.97 \pm 3.57 \\
39.39 \%\end{array}$ & $0.040^{*}$ & $\begin{array}{l}15.94 \pm 2.68 \\
56.93 \%\end{array}$ & $\begin{array}{l}15.89 \pm 5.71 \\
56.75 \%\end{array}$ & 0.41 \\
\hline Vit. A ( $\mu \mathrm{g})$ & $\begin{array}{l}477.45 \pm 36.81 \\
47.75 \%\end{array}$ & $\begin{array}{l}523.41 \pm 23.57 \\
52.34 \%\end{array}$ & 0.127 & $\begin{array}{l}537.40 \pm 28.71 \\
53.74 \%\end{array}$ & $\begin{array}{l}549.32 \pm 41.01 \\
54.93 \%\end{array}$ & 0.152 \\
\hline Vit. D $(\mu \mathrm{g})$ & $\begin{array}{l}4.06 \pm 0.23 \\
40.60 \%\end{array}$ & $\begin{array}{l}3.84 \pm 1.02 \\
38.40 \%\end{array}$ & 0.440 & $\begin{array}{l}4.31 \pm 1.04 \\
43.10 \%\end{array}$ & $\begin{array}{l}4.30 \pm 1.21 \\
43.00 \%\end{array}$ & 0.532 \\
\hline Sodium (mg) & $\begin{array}{l}1481.01 \pm 37.10 \\
98.73 \%\end{array}$ & $\begin{array}{l}1538.99 \pm 35.24 \\
102.59 \%\end{array}$ & 0.341 & $\begin{array}{l}1547.84 \pm 28.37 \\
103.19 \%\end{array}$ & $\begin{array}{l}1550.39 \pm 50.12 \\
103.36 \%\end{array}$ & 0.390 \\
\hline Potassium (mg) & $\begin{array}{l}2970.69 \pm 11.90 \\
63.21 \%\end{array}$ & $\begin{array}{l}3324.79 \pm 31.07 \\
70.74 \%\end{array}$ & 0.260 & $\begin{array}{l}3297.21 \pm 41.20 \\
70.15 \%\end{array}$ & $\begin{array}{l}3302.94 \pm 25.02 \\
70.28 \%\end{array}$ & 0.274 \\
\hline Calcium (mg) & $\begin{array}{l}785.84 \pm 39.81 \\
65.48 \%\end{array}$ & $\begin{array}{l}687.96 \pm 28.91 \\
57.33 \%\end{array}$ & 0.211 & $\begin{array}{l}824.20 \pm 32.11 \\
68.68 \%\end{array}$ & $\begin{array}{l}828.30 . \pm 24.17 \\
69.03 \%\end{array}$ & 0.384 \\
\hline Iron (mg) & $\begin{array}{l}6.14 \pm 0.33 \\
51.17 \%\end{array}$ & $\begin{array}{l}5.87 \pm 2.30 \\
48.92 \%\end{array}$ & 0.300 & $\begin{array}{l}6.01 \pm 3.54 \\
40.07 \%\end{array}$ & $\begin{array}{l}5.96 . \pm 3.08 \\
39.73 \%\end{array}$ & 0.321 \\
\hline Zinc (mg) & $\begin{array}{l}6.49 \pm 0.44 \\
43.27 \%\end{array}$ & $\begin{array}{l}6.34 \pm 1.97 \\
42.27 \%\end{array}$ & 0.337 & $\begin{array}{l}6.31 \pm 1.13 \\
52.58 \%\end{array}$ & $\begin{array}{l}6.24 \pm 1.40 \\
52.00 \%\end{array}$ & 0.341 \\
\hline SFAs (g) & $28.71 \pm 0.61$ & $35.21 \pm 5.27$ & 0.214 & $38.71 \pm \pm 11.07$ & $39.95 \pm 11.04$ & 0.226 \\
\hline MUFs(g) & $29.28 \pm 0.43$ & $32.14 \pm 6.39$ & 0.170 & $35.28 \pm 8.91$ & $36.32 \pm 8.31$ & 0.122 \\
\hline PUFAs (g) & $25.26 \pm 0.35$ & $29.38 \pm 7.44$ & 0.410 & $30.27 \pm 9.15$ & $32.08 \pm 11.16$ & 0.241 \\
\hline Cholesterol (mg) & $223.11 \pm 6.74$ & $385.97 \pm 27.11$ & $0.040^{*}$ & $387 \pm 21.02$ & $399.40 \pm 40.24$ & $0.054^{*}$ \\
\hline
\end{tabular}


Table 5 Correlation coefficients between blood pressure (Systolic \& Diastolic) and some of the daily nutrients intake of obese adolescents

\begin{tabular}{|c|c|c|c|c|c|c|c|c|}
\hline \multirow[t]{3}{*}{ Items } & \multicolumn{4}{|l|}{ Male } & \multicolumn{4}{|l|}{ Females } \\
\hline & \multicolumn{2}{|c|}{ Normal (n:20) } & \multicolumn{2}{|c|}{ Pre hypertensive (n:15) } & \multicolumn{2}{|c|}{ Normal (n:26) } & \multicolumn{2}{|c|}{ Pre hypertensive (n:16) } \\
\hline & Systolic & Diastolic & Systolic & Diastolic & Systolic & Diastolic & Systolic & Diastolic \\
\hline Calcium & -0.237 & -0.178 & -0.241 & -0.231 & -0.130 & -0.080 & -0.331 & -0.236 \\
\hline Sodium & 0.243 & 0.033 & 0.318 & 0.106 & 0.304 & 0.056 & 0.371 & 0.180 \\
\hline S FAs & 0.138 & 0.026 & 0.226 & 0.212 & 0.374 & 0.310 & 0.308 & 0.372 \\
\hline Cholesterol & 0.278 & 0.032 & 0.294 & 0.301 & 0.088 & 0.091 & 0.210 & 0.112 \\
\hline
\end{tabular}

lower percent muscle mass $(\mathrm{P}<0.05)$ than children with ordinary BP. One fourth of the young were overweight and more than $10 \%$ were obese. Data of this study found that $42.86 \%$ of the adolescent males and $38.80 \%$ of the adolescent females were prehypertensive while no hypertensive cases were accounted. Most of the anthropometric parameters of the prehypertensive participants were significantly higher compared to those with normal blood pressure, even though both were complaining from obesity.

Regarding the dietary factors the results obtained in this study showed that the mean daily caloric intake among the prehypertensive groups was high compared to the normal one; the same results were found as regard the three major macronutrients (protein, fat and carbohydrate). The reported mean values of the daily intake of vitamin A and vitamin D were low in both groups the prehypertensive and the control, which was marked in the daily intake of vitamin D among the prehypertensive adolescent boys $(38.04 \%$ of the RDA).

The daily minerals intake showed different pictures, the mean daily calcium intake was low especially in the prehypertensive males, while the mean daily intake of sodium was high in the prehypertensive groups, males and females. A current report expressed that in Indian young people most of micronutrients (mineral and vitamins) consumption were lower than prescribed recommended daily allowance (RDA) for similar age group, calcium consumption was altogether lower in group with hypertension [16]. Calcium also plays role in obesity which subsequently affects the level of blood pressure. It has been reported that consumption of roughly about $1500 \mathrm{mg} /$ days of calcium could help in the reduction of body and truncal fat. In this context consumption of $1000 \mathrm{mg} /$ day of calcium which is equal to the RDAs for daily calcium intake of young adult was recommended [18]. Additionally a positive association between sodium excretion and obesity among Iranian children and adolescents was found [34] which supports our findings.

In the present study our data showed that the mean daily consumption of the saturated fat and cholesterol was high among the prehypertensive groups compared to the control. l'Allemand-Jander [35] expressed that independent of BMI, the nature of fat and protein consumption anticipated hypertension. A current report has exhibited that higher consumption of cholesterol and saturated fat are related with increase BP; in spinal cord injured people with hypertension dietary adjustments with lessening of cholesterol and saturated fat alongside consumption of docosahexaenoicacid (DHA) supplements may decrease BP [36]. In this setting for all children and adolescents one year of age and more, the Cardiovascular Health Integrated Lifestyle Diet (CHILD-1) established that consume less calories is the initial phase in starting the objective of a healthy life. Key to this underlying dietary suggestion is confining saturated fat consumption to $<10 \%$ of every day calorie intake and decreasing cholesterol consumption to < $300 \mathrm{mg} /$ day [37]. In this study the results of the biochemical analysis revealed type of dyslipideamia among the prehypertensive groups, the total cholesterol concentration was $219 \pm 8.66$ and $208 \pm 10.02$ and LDL-C was $176.86 \pm 7.56$ and $171.98 \pm 8.77$ for prehypertensive males and females respectively, that might be the result of the high content of both the saturated fatty acids and the cholesterol in their diet, dyslipideamia in childhood and adolescence is a risk factor for future atherosclerosis and hypertension.

In conclusion, this study showed a high incidence of pre-hypertension among obese Egyptian adolescents. Additionally the study has demonstrated the association between some dietary factors with increased BP. Higher intakes of sodium, cholesterol and saturated fat, along with low intake of calcium are associated with increased BP. Additionally we recommended that the prehypertensive adolescents must improve their food intake and their lifestyle to avoid the development of hypertension in their future time. Further investigation through longitudinal studies using a more representative sample of adolescents is suggested to consolidate the results obtained. 
to acknowledge everybody who participated in this study; the adolescents who were the participants of this study and their parents for their cooperation, the technicians who helped in the laboratory analysis and the doctors who participated in collection of the data. Without their help, this study couldn't have been completed.

\section{Authors' contributions}

NEH is the PI of the project from which this data was derived. NEH and SMES: Conception and design of the study. SAE-M: Preparation of the article for publication. She is the Co-PI of the project from which this data was derived and the corresponding author. NHA:Responsible for nutritional analysis and interpretation of the data. GSME-S and DE-L: responsible for laboratory investigations. MMA:Share in data collection and drafting the article. All authors share in data collection, drafting the article and final approval of the version to be submitted.

\section{Competing interests}

The authors declare that there are no financial and personal relationships with other people or organizations that could inappropriately influence (bias) the present work.

\section{Author details}

'Biological Anthropology Department, Medical Research Division, National Research Centre, 33 El-Bohooth St., Dokki, Giza 12622, Egypt. ${ }^{2}$ Nutrition and Food science Department, Food Industries Division, National Research Centre, Giza, Egypt. ${ }^{3}$ Medical Biochemistry Department, Medical Research Division, National Research Centre, Giza, Egypt. ${ }^{4}$ Clinical Pathology Department, Medical Research Division, National Research Centre, Giza, Egypt.

\section{Received: 25 July 2018 Accepted: 24 November 2018}

\section{Published online: 01 November 2019}

\section{References}

1. O'Shaughnessy KM (2006) Role of diet in hypertension management. Curr Hypertens Rep 8:292-297

2. Paradis G, Lambert M, O'Loughlin J et al (2004) Blood pressure and adiposity in children and adolescents. Circulation. 110:1832-1838

3. Sorof JM, Lai D, Turner J, Poffenbarger T, Portman RJ (2004) Overweight, ethnicity, and the prevalence of hypertension in school-aged children. Pediatrics. 113:475-482

4. Genovesi S, Giussani M, Pieruzzi F et al (2005) Results of blood pressure screening in a population of school-aged children in the province of Milan: role of overweight. J Hypertens 23:493-497

5. Saleh EA, Mahfouz AA, Tayel KY, Naguib MK, Bin-AL-Shaikh NM (2000) Study of blood pressure levels among Kuwaiti primary school children. East Mediterr Health J 6:333-337

6. Jaddou HY, Bateiha AM, Khawaldeh AM, Goussous YM, Ajlouni KM (2001) Blood pressure profile in schoolchildren and adolescents in Jordan. Ann Saudi Med 21:123-126

7. Darwish O, El Ghamry A, Hussein M, Omara S (1985) Prevalence and some etiological factors of hypertension in school children. Bull High Instit Public Health 15:97-110

8. Bonita F (2010) Hypertension in children and adolescents: epidemiology and natural history. Pediatr Nephrol 25:1219-1224

9. Chen X, Wang Y (2008) Tracking of blood pressure from childhood to adulthood: a systematic review and meta-regression analysis. Circulation. 117:3171-3180

10. Sun SS, Grave GD, Siervogel RM, Pickoff AA, Arslanian SS, Daniels SR (2007) Systolic blood pressure in childhood predicts hypertension and metabolic syndrome later in life. Pediatrics. 119:237-246

11. Sundström J, Neovius M, Tynelius P, Rasmussen F (2011) Association of blood pressure in late adolescence with subsequent mortality: cohort study of Swedish male conscripts. BMJ. 342:d643

12. Sugiyama T, Xie D, Graham-Maar RC, Inoue K, Kobayashi Y, Stettler N (2007) Dietary and lifestyle factors associated with blood pressure among U.S. adolescents. J Adolesc Health 40:166-172

13. He FJ, MacGregor GA (2010) Reducing population salt intake worldwide: from evidence to implementation. Prog Cardiovasc Dis 52:363-382

14. He FJ, MacGregor GA (2006) Importance of salt in determining blood pressure in children: meta-analysis of controlled trials. Hypertension. 48:861-869
15. Chen J, Gu D, Huang J et al (2009) Gen Salt Collaborative Research Group. Metabolic syndrome and salt sensitivity of bloodpressure in non-diabetic people in China: a dietary intervention study. Lancet. 373:829-835

16. Kajale NA, Mughal Z, Khadilkar V, Chiplonkar SA, Khadilkar A (2016) Association of dietary calcium intake and body fat with hypertension in Indian adolescents. Indian Pediatr 53(5):434-435

17. Mushengezi B, Chillo P (2014) Association between body fat composition and blood pressure level among secondary school adolescents in Dar es Salaam, Tanzania. Pan Afr Med J 19:327

18. Skinner ML, Simpson JA, Buchholz AC (2011) Dietary and total calcium intakes are associated with lower percentage total body and truncal fat in young, healthy adults. J Am Coll Nutr 30:484-490

19. Morikawa Y, Nakagawa H, Okayama A et al (2002) A cross-sectional study on association of calcium intake with blood pressure in Japanese population. J Hum Hypertens 16:105-110

20. Ghotboddin Mohammadi S, Mirmiran P, Bahadoran Z, Mehrabi Y, Azizi F (2015) The association of dairy intake with metabolic syndrome and its components in adolescents: Tehran lipid and glucose study. Int J Endocrinol Metab 13:e25201

21. Lozano P, Henrikson NB, Morrison CC, Dunn J, Nguyen M, Blasi PR, Whitlock EP (2016) Lipid screening in childhood and adolescence for detection of multifactorial dyslipidemia: evidence report and systematic review for the US preventive services task force. JAMA. 9(3166):634-644

22. Hiernaux J, Tanner JM (1969) Growth and physical studies in human biology: a guide to field methods

23. World Food Dietary Assessment System, (MFDAS), USA, University of California; 1995

24. Falkner B, Daniels SR (2004) Summary of the fourth report on the diagnosis, evaluation, and treatment of high blood pressure in children and adolescents. Hypertension. 44:387-388

25. Allain CC, Poon LS, Chen CSG, Richmond W, Fu PC (1974) Enzymatic determination of total serum cholesterol. Clin Chem 20:470-475

26. Fossati $P$, Prencipe $L$ (1982) Serum triglycerides determination colorimetrically with an enzyme that produces hydrogen peroxide. Clin Chem 28:2077-2088

27. Burstein M, Scholnick HR, Morfin R (1970) Rapid method for the isolation of lipoproteins from human serum by precipitation with polyanions. J Lipid Res 11:583-595

28. Friedewald WT, Levy RI, Fredrickson DS (1972) Estimation of the concentration of low density lipoprotein in plasma, without use of the preparative ultracentrifuge. Clin Chem 18:499-502

29. Beguinot F, Nigro C (2012) Measurement of glucose homeostasis in vivo: glucose and insulin tolerance tests. Methods Mol Biol 933:219-228

30. Berenson GS, Srinivasan S, Bao W, Newman W, Tracy R, Wattigney W (1998) Association between multiple cardiovascular risk factors and atherosclerosis in children and young adults. The Bogalusa Heart Study. N Engl J Med 338:1650-1656

31. Juonala M, Järvisalo M, Mäki-Torkko N, Kähönen M, Viikari J, Raitakari O (2005) Risk factors identified in childhood and decreased carotid artery elasticity in adulthood: the Cardiovascular Risk in Young Finns Study. Circulation. 112:1486-1493

32. Kwiterovich P, Gidding S (2012) Universal screening of cholesterol in children. Clin Cardiol 35:662-664

33. Raj M, Sundaram R, Paul M, Kumar K (2010) Blood pressure distribution in Indian children. Indian Pediatr 47:477-485

34. Rafie N, Mohammadifard N, Khosravi A, Feizi A, Safavi SM (2017) Relationship of sodium intake with obesity among Iranian children and adolescents. ARYA Atheroscler 13:1-6

35. I'Allemand-Jander D (2010) Clinical diagnosis of metabolic and cardiovascular risks in overweight children: early development of chronic diseases in the obese child. Int J Obes 34(Suppl 2):S32-S36

36. Sabour H, Norouzi-Javidan A, Soltani Z, Mousavifar SA, Latifi S, Emami-Razavi SH, Ghodsi SM (2016) The correlation between dietary fat intake and blood pressure among people with spinal cord injury. Iran J Neurol 15:121-127

37. Regis A (2013) The CHILD 1 diet: from strategy to practicality. Pediatr Ann 42:178-180

\section{Publisher's Note}

Springer Nature remains neutral with regard to jurisdictional claims in published maps and institutional affiliations. 